\title{
GREEN CITIES: AN ANALYSIS OF THE ENVIRONMENTAL MANAGEMENT STRATEGY IN THE CITY OF PARAGOMINAS - PARÁ - BRAZIL
}

\section{${ }^{1}$ Camila Da Costa De Sousa, ${ }^{2}$ Rafaela Rodrigues Lins, ${ }^{3}$ José De Lima Albuquerque, ${ }^{4}$ Jorge Da Silva Correia Neto, ${ }^{5}$ Ivanda Maria Martins Silva, ${ }^{6}$ Eliabe Roberto De Souza, ${ }^{7}$ Gelsomina Maria Bignetti Veloso and ${ }^{8}$ Giovanni Giuseppe Da Nóbrega Marinho}

\begin{abstract}
${ }^{1}$ Bachelor in Public Administration from the Federal Rural University of Pernambuco, Brazil; ${ }^{2}$ Professor at Federal Rural University of Pernambuco, Brazil; ${ }^{3}$ Full Professor - Management Department, Federal Rural University of Pernambuco, Brazil; 4. Professor - Academic Unit of Distance Education and Technology at the

Federal Rural University of Pernambuco, Brazil; 5 Professor - Academic Unit of Distance Education and Technology at the Federal Rural University of Pernambuco, Brazil. ${ }^{6}$ Researcher at the Academic Unit of Distance Education and Technology at the Federal Rural University of Pernambuco, Brazil; ${ }^{7}$ Master in Technology and Management in Distance Education, Federal Rural University of Pernambuco, Brazil; 8Student in the Professional Master's in public Administration at the Federal Rural University of Pernambuco, Brazil.
\end{abstract}

\begin{tabular}{|c|c|}
\hline ARTICLE INFO & ABSTRACT \\
\hline Article History: & \multirow{5}{*}{$\begin{array}{l}\text { The growth of environmental awareness and preservation and the search for new ways to manage } \\
\text { natural resources can minimize the predatory occupation of the Amazon. As a result of this fact, } \\
\text { civil society and public authorities developed the Green Municipality project, as a strategy to } \\
\text { reconcile production with good environmental practices, in the municipality of Paragominas, state } \\
\text { of Pará, Brazil. The research data came from interviews with representatives of the public power in } \\
\text { addition to bibliographic and documentary research carried out to analyze the characteristics of } \\
\text { this model of environmental management in the municipality of Paragominas-Pará. According to a } \\
\text { public manager, the group of family farmers was the most resistant to the implementation of the } \\
\text { project in the municipality, as they used the method of clearing and burning the forest on } \\
\text { properties for charcoal production and opening new areas for production. Thus, the adoption of an } \\
\text { environmental management system does not mean harm and becomes a possible reality even in the } \\
\text { Amazon region, which is the scene of so many conflicts, if the social actors act in a collaborative } \\
\text { way and the state seeks to mediate interest of both, as well as the search for improvements is } \\
\text { constant. }\end{array}$} \\
\hline $\begin{array}{l}\text { Received } 18^{\text {th }} \text { February, } 2021 \\
\text { Received in revised form } \\
11^{\text {th }} \text { March, } 2021 \\
\text { Accepted } 20^{\text {th }} \text { April, } 2021 \\
\text { Published online } 30^{\text {th }} \text { May, } 2021\end{array}$ & \\
\hline Key Words: & \\
\hline $\begin{array}{l}\text { Amazon, Green Municipality, } \\
\text { Environmental Management. }\end{array}$ & \\
\hline $\begin{array}{l}\text { *Corresponding author: } \\
\text { Camila Da Costa De Sousa, }\end{array}$ & \\
\hline
\end{tabular}

Copyright (C) 2021, Camila Da Costa De Sousa et al. This is an open access article distributed under the Creative Commons Attribution License, which permits unrestricted use, distribution, and reproduction in any medium, provided the original work is properly cited.

Citation: Camila Da Costa De Sousa, Rafaela Rodrigues Lins, José De Lima Albuquerque, Jorge Da Silva Correia Neto, Ivanda Maria Martins Silva, Eliabe Roberto De Souza, Gelsomina Maria Bignetti Veloso and Giovanni Giuseppe Da Nóbrega Marinho, 2021. "Green cities: an analysis of the environmentalmanagement strategy in the city of Paragominas - Pará - Brazil”, International Journal of Development Research, 11, (05), $47101-47105$.

\section{INTRODUÇÃO}

In the last decades, the way in which human beings have organized themselves on the planet has undergone intense changes - such as the rural exodus and the formation of large metropolises - as a result of this, the way of life has also been transformed, the subsistence production was gradually being replaced by manufactured products, which generate practicality leading to increasing consumption, which leads to the indiscriminate use of natural, renewable and nonrenewable resources and the consequent increase in waste production. With the perception of the impossibility of maintaining this mode of production for a long time, the need for a new model of man's relationship with the environment became evident. The Attention to environmental issues gained strength in the last three decades of the 20 th century and became increasingly widespread in the 21 st century. Thus, environmental management has become indispensable for the good development of the activities of any organization, with a view to using natural resources in a rational way (Ruppenthal, 2014). As a result of this popularization, governments around the world began to devise measures to reduce man's aggression to the environment, including Brazil. According to Guimarães, Veríssimo, Amaral, and Demachki (2011), from 2007, the federal government launched decisive measures to combat deforestation in the Amazon. These measures transferred responsibility for combating deforestation to municipalities, restricted rural credit to irregular producers, made 
responsible the entire supply chain responsible for deforestation, in addition to providing a list of offenders and municipalities where deforestation had reached critical levels. Due to the negative consequences felt by municipalities in the Amazon region, leaders looked for a way to get around them, the municipality of Paragominas, located in the state of Pará, is among those that sought to implement activities that mitigate environmental degradation, having elaborated the Green Municipality project. Paragominas is a city located in the southeastern mesoregion of the state of Pará, with an area of $19,342.254 \mathrm{~km}^{2}$ and an estimated population of 111,764 inhabitants. This municipality was included in the list of priority Amazonian municipalities for actions to prevent, monitor and control illegal deforestation, a list that was elaborated and disseminated by the Ministry of the Environment (MMA). In this sense, this work has as general objective to characterize the green municipality project of Paragominas as an alternative of environmental management, as well as presents the following specific objectives: To identify and characterize the green municipality project in Paragominas - PA and to analyze the advantages of a system of environmental management for producers and rural companies in the aforementioned municipality. As a research problem, on the one hand, there is a worldwide realization of the need for the rational use of natural resources, but in contrast, cities or entire countries do not adopt any methodology for reducing environmental impacts. Therefore, this work intends to analyze the theme of environmental management from the analysis of the green municipality project in the city of Paragominas - PA - Brazil

\section{Theoretical Foundation}

Environmental Management: About the term management Brito (2009) claims to be a nomenclature adopted since the 1990s to refer to a more participative administration, both of people and of material resources, in the public and private sphere, giving the term a multidisciplinary character, thus enabling it in various areas. However, its application regarding natural resources is recent, even though man is always dependent on nature for his survival and productive processes. To approach environmental management, it is necessary to conceptualize its objective: the environment. Article 3 of the Law 6938/81, which governs the National Environment Policy (PNMA), defines it as"The set of conditions, laws, influences and interactions of a physical, chemical and biological order, which allows, shelters and governs life in all its forms" (Brasil, 1981, p.01). Over the years, societies have undergone major changes in their habits and the improvement of activities, the industrial revolution, for example, was a major milestone for the consolidation of the world as it is known today. As a consequence, the form of production was modified (from manually produced to those produced by machines), consumption (mass production provided a greater quantity of products with a lower price, which made consumption increase) and also the amount of resources used for the manufacture of these. In the 20th century, man began to realize that nature would not be able to maintain this intense and growing demand and that it was necessary to search for new ways of relating to the environment. From this premise, environmental management emerges as a means of minimize the impacts caused by the productive activities that sustain our way of life. Quintas (2006, p. 30) defines environmental management as being:

[...] The process of mediation of interests and conflicts (potential or explicit) between social actors who act on the physical-natural and built environment, aiming to guarantee the right to an ecologically balanced environment, as determined by the Federal Constitution.

This definition is similar to what Campaner, Araújo, and Pinheiro (2009) say when they state that environmental management can be understood as an apparatus of actions, strategies and procedures to ensure the integrity of both the biotic and physical environment and the social groups that depend on them. Ruppenthal (2014), on the other hand, conceptualizes environmental management from a corporate point of view, defining it as a set of methods that aims to guide the business organization to understand, control and reduce the environmental impacts of its activities, products or services. In this sense, the objective of the environmental management is based on the deduction that the producer or company that decides to implement an environmental management will balance the measures and actions adopted based on what is available (and possible) of return, from the environmental and market point of view, knowing that the goal of every entrepreneur is to keep him in the market, whether he is in a micro or macro sphere (Dal Forno, 2017). The tools for the adoption of this management are called environmental management systems that Dal Forno (2017) defines as the adoption of measures that reduce the environmental impact of some production process, be it the replacement of a certain product with a less aggressive one, reduction of the emission polluting gases, proper disposal of waste generated or optimization of the production of an area, regardless of the scale of this process.

Environmental Management in Brazil: In Brazil, the first legislation aimed at the use of natural resources occurred after the promulgation of the 1934 constitution, including: Water Code (1934), Fishing Code (1938), Hunting Code (1943), Forestry Code (1934) and Mining Code (1940) (Oliveira, 2014). According to Moura (2016) at that time there was no environmental policy in fact, these laws were only sectoral and focused on the rational control of resources for better economic use. Although the need to adopt techniques to reduce the impacts of human activities on the environment is old, productive organizations at a global level only began to recognize them and pay attention to their importance at the beginning of the last century. As Nascimento (2012) points out, the $1960 \mathrm{~s}$ is the period in which considerable growth in environmental awareness begins, with the Biosphere conference in Paris in 1968 and the creation of the Rome Club, where scientists elaborated and published a report, entitled Limits to Growth (1972) on the risk of economic growth based on non-renewable natural resources; besides collaborating for the creation of the United Nations Conference on Environment and Development, in Stockholm, Sweden in July 1972, where the United Nations Environment Program originated, which inserts environmental concerns into the global agendas (Nascimento, 2012). Brazil's position at the Stockholm Conference was reactionary, along with the other underdeveloped countries; These countries advocated economic and population growth over environmental issues, and even that developed countries should bear the costs for protecting the environment. Despite resistance to these ideas in 1973, the Environment Secretariat (SEMA) was created at the federal level, in Brazil, being the first unit to deal with environmental issues at the national level (Moura, 2016).

A few years later, the National Environment Policy (PNMA) was published in 1981, Law No. 6,938, which instituted the National Environment System (SISNAMA), of which the federal, state and municipal environment bodies are part, and the National Environment Council (CONAMA), a normative and deliberative body, in addition to state and municipal councils, also members of SISNAMA (Cruz, 2011). Still in the 1980s, Article 225 of the Brazilian Constitution, promulgated in 1988, summarized the concern with environmental preservation: "Everyone has the right to an ecologically balanced environment, good for the common use of the people and essential to a healthy quality of life, imposing on the Public Power and the community the duty to defend and preserve it for present and future generations" (Nascimento, 2012, p. 18). The World Bank later released its report on Development and the Environment in 1992, the same year it was held in Rio de Janeiro; the Second World Conference on the Environment, also called Rio-92. This meeting resulted in two documents that would guide the actions to be taken by the various signatory countries to this convention: The Earth Charter (also called the Rio Declaration) and the Agenda 21 (Scardua, 2003). In the same year as Rio-92, the Ministry of the Environment (MMA) was created. Another legal framework, after the Federal Constitution, was the publication of the Environmental Crimes Law $\left(n^{\circ} 9,605\right)$, in 1998, and the National Water Resources Policy $\left(\mathrm{n}^{\circ}\right.$ 9,433), in 1997. Both expanded the jurisdiction at the local level by making it possible that states and municipalities become competent authorities for 
inspection (Cruz, 2011). Environmental management in Brazil is characterized by the use of command-control instruments (through licenses, norms, zoning, standards, inspection and monitoring), established by the National Environment Policy - PNMA. Its dissemination originated from the recommendations of the Stockholm Conference. These types of instruments have not proved to be sufficient to remedy or mitigate the environmental impacts arising from human activities. In this sense, a new set of environmental management instruments started to be integrated into Brazilian practices, based on the polluter-pays principle. This new set of instruments may appear in the form of pollution fees, subsidies, tax exemptions, amortization facilities or credits and negotiable authorizations for the rights to pollute (Scardua, 2003). The decentralization of Brazilian environmental management is a way of solving the problems of the heterogeneity of the country's biomes, where each municipality can develop a form of management that suits its reality, according to what governs the union. The National Environment System (SISNAMA) is composed of all bodies, at different scales, responsible for environmental improvement and protection, as well as mediating civil society's access to its activities, as can be seen in Table 1 .

Environmental Management in Pará State: The emergence of the conflict between the demands for preservation of the Amazon biome by entities and governments of an external reality is not recent, these social actors do not have half the knowledge of the complexity of this biome and all the peoples inserted in it, nor how these peoples were inserted and the culture to which they were established, in addition to the adoption of sustainable measures by those who actually live, work, profit and undertake in this area. Whether because of a culture long before adopted, or because of resistance to new ideas, because of the difficulty in accessing information or simply because of negative behaviors. These concerns and demands are due to the change in thinking in the global sphere regarding the preservation of the environment, but for the Amazon region, this change was a direct shock to the occupation policies that were happening at the time. For May,Millikan, Amaral, and Ascher (2005) the population of this region has become a priority due to internal factors as a solution to the social problems of the northeast region of the Brazil and expansion of the commercial center of the Southeast region, and of an external order such as border protection and guarantee of Brazil's exploration of the natural resources of the Amazon rainforest, once other neighboring countries also had plans to occupy it. With the end of the national developmentalism plan, the process of globalization, the process of organizing civil society in Brazil, in addition to redemocratization, brought about intense and comprehensive change in the country and in the Amazon, and in contrast to the previous period, parallel public policies and Conflicting measures were implemented in the Amazon, as is the case of the environmental policy of the Ministry of the Environment and the development policy of the Ministry of Planning, Budget and Management (MP) (May et al., 2005).

Green Municipality Project: The Green Municipality Project is an environmental policy adopted by the municipality of Paragominas / PA and later by the state of Pará as the Green Municipality State Program. Guimarães et al. (2011) defines a green municipality as: a municipality that develops sustainable productive activities with low carbon emissions and high social and environmental responsibility. In the Amazon, the green municipality encourages: (I) local governance for broad municipal management of the environment; (II) forest management; (III) the intensification of agriculture and reforestation; (IV) the sustainable use and conservation of the ecological functions of forests and remnants; and (V) the recovery of Permanent Preservation Areas (APP) and Legal Reserve Areas (ARL). In addition, the municipality defines and carries out local monitoring actions of productive activities and pressure on the forest as an effective measure to combat deforestation and promotes the inclusion of all producers in the Rural Environmental Registry (CAR) and in the Rural Environmental Licensing (LAR). With these actions, the municipality creates bases for legal security, which allows attracting quality investments (Guimarães et al., 2011). In 2008, the Ministry of the Environment (MMA) edited and released the first list of priority Amazonian municipalities for actions to prevent, monitor and control illegal deforestation. Among the consequences felt by the application of the Action Plan for the Prevention and Control of Deforestation in the Legal Amazon (PPCDAM), are, in addition to the disclosure of the list, also measures to repress illegal deforestation, such as the arc of fire operation, carried out in 2008 and the restriction to rural credit aiming at the decapitalization of rural producers, signaled as the biggest supporters of deforestation (Carneiro and Assis, 2015). Political leaders, producers and companies faced an extremely uncomfortable situation, both for the image of the city and the agricultural products that operated in the municipality. The city hall of Paragominas, together with the main local civil entities, sought an articulation of a means to reverse this process and the removal of the municipality from the list of critical deforestation status. The mayor of the city at the time stated that on February 28, 2008, a meeting was held in the auditorium of the city hall, with 51 entities, in which the Zero Deforestation Pact was launched, which would have as its objective not to deforest anymore and try to work properly. sustainable development in already open areas of the city (CARNEIRO; ASSIS 2015).

After the pact, measures to decentralize environmental management were taken with the transfer of some powers of inspection and environmental licensing from the state secretariat for the environment to the municipal secretariat. In order to make the monitoring of this commitment feasible, the city demanded the support of the Instituto do Homem da Amazônia (IMAZON), a non-governmental organization with a long tradition of research in the municipality of Paragominas, to mediate this agreement. Even so, some activities caused an intense deforestation in the city, such as the production of charcoal and the removal of wood from the indigenous reserve of the upper Guamá.So, a second operation was carried out, called "arc of fire", even more intense, with seizure of assets, fines and imprisonment of those responsible for these activities by the Brazilian Environmental Institute (IBAMA). This operation generated a confrontation with the population, with some businessmen wanting to recover their assets by the use of force, in addition to threats to public agents, which resulted in an arson in the IBAMA office in the city of Paragominas (Carneiro and Assis, 2015). As a reaction, the city has prepared a document to present to the Ministry of the Environment (MMA), detailing the project of the Green Municipality. This document, written in the form of a Letter of Commitment (Lucena, 2011), in addition to reinforcing the previous commitment to control deforestation, proposed the development of economic activities to standards considered sustainable" (Carneiro and Assis, 2015). From then on, the Rural Environmental Registry (CAR) began to be carried out on the properties of the municipalities, which consisted of one of the criteria for removing the "dirty list from deforestation". In 2009, $80 \%$ of the properties had already completed their registration. making it possible to leave this list and in 2010.The city of Paragominas passed to the condition of "controlled and monitored deforestation in the Amazon" according to an ordinance published by the MMA. Then, other proposals for sustainable development emerged, such as the "Pact for the Legal and Sustainable Product" and the "Green Livestock Project", in addition to the articulation for the recovery of legal reserves in the areas that constituted another stage of the Green Municipality Project - PMV (Carneiro and Assis, 2015). For producers and rural companies, these good environmental practices add value to their product, in addition to undergoing the evaluation of more stringent markets, such as the export market. In addition to the adoption of new technologies that would increase production without necessarily having to increase the area of activities.

\section{METHODOLOGICAL PROCEDURES}

This section aims to describe the methods used to prepare the research, as well as the instruments that were used to collect information, the conjuncture and the individuals that make up the investigation. This research has a qualitative approach with an 
exploratory objective according to Gerhardt and Silveira (2009). The location for the realization was the municipality of Paragominas, in the state of Pará, which is the cradle of the Green Municipality Project, where it is applied and consolidated. Initially for the elaboration of the research, the goal was to conduct semi-structured interviews, with rural producers and members of the local government that are characterized as the group of interest of this research, which characterizes the method of obtaining data the survey research as described by Gerhardt and Silveira (2009). Due to several factors, it was not possible to conduct interviews with rural producers, several attempts were made to contact them, but all of them were unsuccessful. Interviews were carried out with some members of local government, in the period of December 2018 and January 2019, to which a questionnaire with seven questions was applied. The other data were obtained using bibliographic and documentary research available on the project in the municipality. For the content analysis of the data, the thematic modality was used (Minayo, 2007) and these data were grouped into categories and compared with information from other researchers.
The other actions also had their due impact and the Paraguayan producer wanted to produce legally and improve the image of his city and his product, but if his actions were not previously classified as illegal it would be difficult for an initiative of this proportions to be moved only by pure sense of ecological responsibility.

Benefits of the Green Municipality Project: At the beginning of the implementation of the project, IMAZON coordinated with the state government the elaboration of a Decentralized Management Term $\left(\mathrm{n}^{\circ}\right.$ 002/2008 - SEMA / PA) transferring some competences to the Municipal Environment Secretariat and a technical cooperation term $\left(n^{\circ} 002 / 2008\right.$ - SEMA / PA) with the goal of carrying out "actions linked to the Municipal Plan for the Prevention and Combat of Deforestation" (Lucena, 2011, p.90). There were also other advances made by the municipality in environmental legislation, such as the approval of Law No. 644/07 that governs the municipal environmental policy in Paragominas and the proposal for a Municipal Environmental Code (Galvão, 2013). These articulations allowed the municipality to legislate on issues until then centralized

Table 1. Structure of the National Environment System - SISNAMA

\begin{tabular}{|l|l|l|}
\hline Structural bodies & Constituent bodies & \multicolumn{1}{|c|}{ Function } \\
\hline Superior body & Government Council & $\begin{array}{l}\text { To advise the President of the Republic in the formulation of national policy and } \\
\text { government guidelines for the environment and environmental resources }\end{array}$ \\
\hline $\begin{array}{l}\text { Advisory and deliberative } \\
\text { body }\end{array}$ & $\begin{array}{l}\text { National Environment Council - } \\
\text { CONAMA }\end{array}$ & $\begin{array}{l}\text { To advise, study and propose to the Government Council, governmental policy } \\
\text { guidelines for the environment and natural resources and deliberate, within the } \\
\text { scope of its competence, on norms and standards compatible with the } \\
\text { ecologically environment balanced and essential to a healthy quality of life; }\end{array}$ \\
\hline Central body & $\begin{array}{l}\text { Secretariat for the Environment of } \\
\text { Presidency of the Republic }\end{array}$ & $\begin{array}{l}\text { Plan, coordinate, supervise and control, as a federal agency, national policy and } \\
\text { government guidelines set for the environment }\end{array}$ \\
\hline Executing body & $\begin{array}{l}\text { Brazilian Institute of Environment and } \\
\text { Natural and Renewable Resources }\end{array}$ & $\begin{array}{l}\text { To execute and enforce, as a federal agency, the government policy and } \\
\text { guidelines set for the environment; }\end{array}$ \\
\hline Sectional bodies & State agencies or entities & $\begin{array}{l}\text { Responsible for the execution of programs, projects and for the control and } \\
\text { inspection of activities capable of cause environmental degradation; }\end{array}$ \\
\hline Local bodies & Municipal bodies or entities & $\begin{array}{l}\text { Responsible for the control and inspection of these activities, in their respective } \\
\text { jurisdictions; }\end{array}$ \\
\hline
\end{tabular}

Source: Ministériodo Meio Ambiente (2008).

\section{RESULTS AND DISCUSSION}

Motivations for adopting an Environmental Management System in the municipality of Paragominas: The economy of the city is mostly based on agricultural and timber activities, like most cities in the Amazon, which had their occupation in a predatory manner, building a culture where destruction would be synonymous with profit. The fact that Paragominas was categorized as one of the municipalities that most deforested the Amazon made it the target of some measures of the Action Plan for the Prevention and Control of Deforestation in the Legal Amazon (PPCDAM), among them, the restriction on credit, where Carneiro and Assis (2015) highlight that many producers used this credit to fund their crops and also increased inspection in the city with operations such as Arco de Fogo I and II that generated tensions and conflicts between civil society and government agents. Carneiro and Assis (2015) highlight among these measures, the restriction of credit to rural producers as one of the actions that most impacted the city; which differs from the results obtained where one of the founders of the project stated that the rejection of the market for the city's products was the one that most pressured the change in attitudes of local entrepreneurs. Exporting companies no longer wanted the municipality's soybeans, slaughterhouses no longer bought animals and timber shipments from the city became targets of NGO's protest. The creation and implementation of the PPCDAM together with its command-andcontrol measures making it possible to expose the situation of the municipality that deforested thirty thousand hectares per year. This made the problems in the region visible and clear to the market, which in turn reacted negatively, which generated pressure on the region's entrepreneurs, which is consistent with Cairncross (1992), who states that, where the government needs to intervene, since the invisible hand of the market fails to align the interests of the individual or the individual company with the interests of society. in the state's SEMA ( Municipal Environment Secretariat), such as the granting of environmental licensing, making logistics easier to obtain, more practical and cheaper, making this action more accessible to the producer. Environmental licensing was not the only practice that started to be carried out in the municipality, according to interviewees. As the city had a highly degraded area, IBAMA fined producers who cleaned the area with secondary forest at an early stage of development, the so-called "juquiras", so the municipality created legal bases for granting authorization to clean these areas and since 2014, thirty-seven thousand hectares of juquira were transformed into plantations. Paragominas has also become the only municipality in the state where it is possible to make environmental compensation in the city itself, through the lease of another rural property that has a surplus of vegetation in the legal reserve area as provided by State Decree No. 1,379 / 2015 and Normative Instruction $\mathrm{n}^{\circ} 01$ of 2016.

This facilitation that the project brought did not reach everyone, and for producers and family members it was seen as a loss. As described in one of the interviews with a member of the government: the group of family farmers was the most resistant to the implementation of the project because they used the method of clearing and burning the forest on properties to produce charcoal and opening new areas for their production. According to Carneiro and Assis (2015) the lot size makes it difficult to adapt to environmental legislation and some cases may even make the economic activity exercised by rural workers in rural settlement projects unfeasible, and in large part this kind of rural workers did not have resources for environmental recovery of the settlement and for that they should count on the National Institute of Colonization and Agrarian Reform (INCRA). Also, as stated by a member of the government, after some dialogues with the producers, the city government made some tractors available for cleaning areas without the use of fire, but in a precarious way since the city did not have many resources for this activity. At the 
time of the interviews, most family farmers did not own the CAR on their property, only on the rural settlement as a whole. Public managers highlight difficulties imposed by INCRA as the main cause for not carrying out the CAR on family properties. It should be noted that compliance with the current environmental legislation guarantees tranquility to the producer, knowing that he will not be subject to embargoes, fines, state or market sanctions, which makes it possible to attract new investments as well as the arrival of new producers and companies in the region. As the state prioritized investment in environmentally regulated municipalities, approximately $800 \mathrm{~km}$ of three-phase electrical network was built in the rural area of the city, in addition to the Paragominas Agricultural Fair and AgroShow, where companies can exhibit their products to producers every year. The AgroShow became the largest technology fair in the state. The products from the city started to gain appreciation in the market worldwide. Sometimes the city is cited as an example of sustainable development in the Amazon, with a successful demonstration of reconciliation in production and environmental preservation, and the city welcomes these attributions with great pride, and the producer obviously uses a good image for a good business.

\section{CONCLUSION}

The green municipality project is an environmental management model that has well suited to the situation in the city of Paragominas and has brought with it the trend towards decentralization of environmental management, which is an increasingly used and successful alternative. However, these benefits targeted (and reached) large and medium-sized producers, not putting much effort into the insertion of family producers, so the more influence the target has, the more it will benefit. As the proposal was born in the union of rural entities in the municipality, it ended up not giving due attention to those who did not have enough active voice to directly influence government decisions. In this sense, the project changed positively the reality of the city of Paragominas, helped producers organize their properties and its production methods and thus reestablishing the city's economic base; the project was the starting point for any other environmental management policy that would and will emerge in the city, but it is also necessary to pay attention to different realities within the same municipality. Consequently, the adoption of an environmental management system is not synonymous with prejudice and a possible reality even in the Amazon region that is the scene of so many conflicts, as long as the social actors talk to each other and the state seeks to mediate the interest of both.

\section{REFERENCES}

Amorim ELC (2005). Gestão ambiental. Apostila do curso de Avaliação de Impactos Ambientais. Universidade Federal de Alagoas - UFAL, Engenharia Ambiental. Available at: http://www.ctec.ufal.br/professor/elca/ gest amb.pdf. Access: 11 jan. 2019.

Brasil (1981). Lei $n^{\circ} 6.938$, de 31 de agosto de 1981. Dispõe sobre a Política Nacional do Meio Ambiente, seus fins e mecanismos de formulação e aplicação, e dá outras providências. Casa Civil:

Brito SKM (2009). Parque estadual do Utinga (PA): uma gestão ambiental participativa. Masters Dissertation. Universidade Federal do Pará (UFPA). Belém. Available at: http://repositorio.ufpa.br/jspui/handle/2011/9844. Access: 15 jan. 2019.

Cairncorss F (1992). Making polluters pay. In: Costing the Earth. Cambridge: Harvard Business School Press.

Campaner ECS, Araújo GMS, Pinheiro RC (2009). Gestão ambiental como responsabilidade social das organizações. Monography. Pós-Graduação "Lato Sensu" em Gestão Empresarial com Ênfase em marketing e Recursos Humanos. Lins. Available at: http://www.unisalesiano.edu.br/biblioteca/monografias/48724.pd f. Access: 10 dec. 2018.
Carneiro MS, Assis WS (2015). O controle do desmatamento na Amazônia como um processo de modernização ecológica: a experiência do projeto município verde. Repocs, 12 (24). Available at: http://www.periodicoseletronicos.ufma.br/index .php/rpcsoc/article/view/3640/0. Access: 07 dec. 2018.

Cruz PF (2011). Os desafios da gestão ambiental no Brasil. Observatório de Informações Municipais,

Correio

Dal Forno MAR (2017). Fundamentos em gestão ambiental. Universidade Federal do Rio Grande do Sul. Secretaria de Educação a Distância. Available at: http://www.ufrgs.br/ cursopgdr/downloadsSerie/derad108.pdf. Access: 11 jan. 2019.

Gerhardt TE, Silveira DT (2009). Métodos de pesquisa. Universidade Aberta do Brasil - UAB/UFRGS e Curso de Graduação Tecnológica - Planejamento e Gestão para o Desenvolvimento Rural da SEAD/UFRGS. - Porto Alegre: Editora da UFRGS. Available at: <http://www.ufrgs.br/ cursopgdr/downloadsSerie/derad005.pdf $>$. Access: 10 feb. 2019.

Guimarães J, Veríssimo A, Amaral P, Demachki A (2011). Municípios Verdes: caminhos para a sustentabilidade. Belém, PA: Imazon. Available at: https://imazon.org.br/PDFimazon/ Portugues/livros/GUIA_MUNICIPIOSVERDES.pdf. Access: 07 dec. 2018.

Lucena SL (2011). É possível desenvolver respeitando o meio ambiente? Estudo de caso da experiência do município de Paragominas - Pará. Monography. Especialização em Auditoria da Gestão Municipal do Meio Ambiente. Belém: Núcleo de Meio Ambiente/ UFPA.

May PH, Millikan B, Amaral C, Ascher P (2005). Instrumentos econômicos para o desenvolvimento sustentável na Amazônia brasileira. Brasília: Ministério do Meio Ambiente. 124 p.; 29 cm. Available at: http://www.ppgcasa.ufam.edu.br/pdf/ InstrumEconom.pdf\#page=32. Access: 20 dec. 2018.

MMA, Ministério do Meio Ambiente (2008). Legislação Ambiental Básica. Consultoria jurídica. UNESCO. Brasília. Available at: http://www.mma.gov.br/estruturas/secex conjur/_arquivos/108 12082008084425.pdf Access: 02 jan. $20 \overline{19}$.

Moura AMM (2016). Governança ambiental no Brasil: instituições, atores e políticas públicas- Brasília: Ipea. Available at: http://www.ipea.gov.br/agencia/images/stories/ PDFs/livros/livros/160719 governanca_ambie ntal.pdf. Access: 10 jan. 2019.

Nascimento LF (2012). Gestão ambiental e sustentabilidade. Florianópolis: Departamento de Ciências da Administração/ UFSC; CAPES: UAB. Available at:http://www.cesadufs.com.br/ ORBI/public/uploadCatalago/15365410042013Gestao_Ambient al_Sustentabilidade_Aula_1.pdf. Access: 16 jan. 2019.

Oliveira DA (2014). Evolução da Legislação Ambiental Brasileira. JusBrasil. Available at: https://drdao.jusbrasil.com.br/artigos/ 114762320/evolucao-da-legislacao-ambiental-brasileira. Access: 20 dec. 2018.

Quintas JS (2006). Introdução à gestão ambiental pública. Coleção Meio Ambiente. SérieEducaçãoAmbiental, 5) $2^{\mathrm{a}}$ ed. revista. Brasília: Ibama. Available at: http://www. icmbio.gov.br/educacaoambiental/images/stories/biblioteca/educ acao_ambiental/QUINTAS_Jos\%C3\%A9_Silva_Introdu $\% \mathrm{C} 3 \% \mathrm{~A} 7 \% \mathrm{C} 3 \% \mathrm{~A}_{\overline{3}} \mathrm{O} \% \mathrm{C} 3 \% \mathrm{~A} 0-\mathrm{Gest}^{0} \% \mathrm{C} 3 \% \mathrm{~A} 3 \mathrm{o}$ Ambi enta\$pughefia

Ruppenthal JA (2014). Gestão Ambiental. Santa Maria: Universidade Federal de Santa Maria, Colégio Técnico Industrial de Santa Maria; Rede e-Tec Brasil, 2014. Available at: http://estudio01.proj.ufsm.br/cadernos_seguranca/oitava_etapa/g estao_ambiental.pdf. Access: 06 jan. 2019.

Scardua FP (2003). Governabilidade e descentralização da gestão ambiental no Brasil. Tese de Doutorado Universidade de Brasília. Centro de Desenvolvimento Sustentável. Available at: https://periodicos.feevale.br/seer/index.php/revistagesta oedesenvolvimento/article/download/ 1136/1841. Access: 16 jan. 2019. 